\title{
THE LEAGUE OF NATIONS: LEGAL, POLITICAL AND SOCIAL IMPACT ON ESTONIA
}

\author{
David Ramiro Troitiño ${ }^{1}$ - Tanel Kerikmäe $e^{2}$ Ondrej Hamulák ${ }^{3}$
}

\begin{abstract}
The League of Nations, predecessor of the current United Nations, was the first world organization with a real impact on its members. The organization was created after the WWI in an attempt to establish a stable peace system among its members. Estonia, a country formed after the end of the war, was in a need of international recognition and protection. Hence, the membership was welcome as an anchor to liberty and freedom. This research analyses how the organization influenced Estonia and what were the major contributions of the country in the development of the League of Nations. The aim of the paper is to analyse the concrete impact of the membership on the position and recognition of Estonia as well as the influence of Estonia on the development of key activities of the League of Nations, in particular the questions of refugee protection and return of prisoners of war; protection of minorities (including the support to protection of rights of native American tribes) and attempts to establish the uniform global legal order. A special focus is given also to personal impact represented by the authority of Ragnar Nurkse.
\end{abstract}

KEY WORDS: League of Nations, Estonia, Legal International Organizations, World Peace.

\section{INTRODUCTION}

Estonia, located in the Baltic Sea, is a country with strong connections to the Scandinavian world and the Germanic world. The ups and downs of Estonian history are determined by a concatenation of foreign invasions and the creation of a very strong national identity that triggered the creation of the Estonian nation-state in 1918. The area, including neighbouring Latvia, was colonized for centuries by German knights in a kind of crusade

\footnotetext{
${ }^{1}$ TalTech Law School, Tallinn University of Technology, Akadeemia tee 3, 12618 Tallinn, Estonia; e-mail: david.troitino@taltech.ee.

${ }^{2}$ TalTech Law School, Tallinn University of Technology, Akadeemia tee 3, 12618 Tallinn, Estonia; e-mail: tanel.kerikmae@taltech.ee.

${ }^{3}$ Department of International and European Law, Faculty of Law, Palacký University Olomouc, tr. 17. Listopadu 8, 771 11, Olomouc, Czech Republic \& TalTech Law School, Tallinn University of Technology, Akadeemia tee 3, 12618 Tallinn, Estonia; e-mail: ondrej.hamulak@upol.cz.
} 
to convert local pagans, although in reality it concealed a mere territorial and economic expansion of a German elite founded on land ownership and population servitude. Thus, despite political movements at the highest level, the Danish and later Swedish occupation, the creation of Livonia and incorporation into the Russian empire, the social composition changed relatively little over the centuries. A German minority dominated society through land ownership and a very strict system of servitude.

With the collapse of the Russian empire, first, and then the German empire, Estonia became independent on the basis of its majority composition, a nation, the Estonian, with its own peculiar features, language, traditions and objectives, endowed itself with a political structure to obtain its desired freedom from the yoke imposed for centuries by the Baltic Germans. Independence was forged in the midst of Russia's civil war, which pitted reds against whites in a conflict with many nuances. Estonia quickly took advantage of the situation to disassociate itself from the Russian government, initiating an armed conflict. The Bolsheviks, in order to weaken the tsarist side, isolate the country from foreign interference and free military resources, accepted the independence of numerous nations, such as Finns, Estonians, Latvians, Lithuanians or Poles.

Once a stable peace agreement was reached, the Estonian government began to work to create a stable socio-economic structure that would allow the country to survive internally through an agrarian reform, and externally, it sought to ensure its independence (Medijainen, 2002)

The title of League of Nations was already perfectly suited to Estonia, which had achieved independence on 24 February 1918 on the basis of its national composition. The League of Nations was formally established on 10 January 1920 and Estonia joined on 21 September 1921 when Estonia, Latvia and Lithuania were accepted at the Second General Assembly. Ants Piip, Foreign Minister of the new republic, and the country's representative in various general assemblies, was an important figure in these negotiations. Unfortunately, he was later executed by the NKVD, the predecessor of the $\mathrm{KGB}$, for being a bourgeois.

Estonia was admitted under the promise to implement all the clauses included in the Treaty on the Protection of Minorities developed by the organization and that while the ratification process was delayed, its minorities would enjoy equivalent measures that had to be submitted to the Council of the League of Nations. Estonia was also prevented from building large submarines by British imposition and as a prerequisite for acceptance into the new international organisation (Ellis, 1929). 
This research aims to focus on the controversial membership of Estonia in the League of Nations as a way to achieve independence in a global world led by Western States and protect itself from the Soviet threat. Hence, it follows a structure based on the main aspects concerning the Estonian hopes and its implications in the League of Nations. The imposition of a model of organization based on cooperation by United Kingdom is analyzed under this prism, following with the idea of an organization working to prevent wars, the analysis of the fields successfully implicated and its consequences over Estonia, and how the organization focused on domestic issues with a great impact on the Estonian security, as the protection of minorities. The article describes the positive and negative aspects of the Estonian membership in the League of Nations as a way to understand its impact in the later occupation of the country by the Soviet troops. The performance of the country, regarding the Six Nations case and the participation of Ragnar Nurske as a high official, also represent somehow the Estonian priorities inside the organization, basic to understand the whole process of membership in the League of Nations and the later development of the country.

The paper has been developed under the prism of new historicism theory that evaluates literature and events through a comprehensive analysis of the social and cultural circumstances that surround the topic being described and so much more how these socio-cultural events help to build the event. Hence a qualitative research has been implemented for a wider understanding of a lost opportunity in Europe and the world to build a stable peace system through the comprehensive international organization that could have helped Estonia to keep its independence in the early XX century.

The theoretical framework of the research is based on historicism approach link with potential implications with the main target of the investigation, the influence of the League of Nations on independent Estonia and its influence on the relations with the USSR. Hence, a systematic approach on the past historic events explains a complex process on time, from the Estonian independence until the Soviet occupation. The main research object of this research is presented as a part of a whole, as a part of a system, the participation of Estonia in the League of Nations in a wider perspective to understand a specific topic. Hereafter, Historicism is used as the main theory for the whole analysis to understand a partial element. The current state of knowledge is very limited to the Estonian historians and political science specialists, and has not been developed further to the international community. First, the topic is briefly treated by general 
publications about the League of Nations. There are some remarkable works, the work of Francis Paul Walters who himself was closely associated to the League of Nations (Walters, 1952), Northedge, who researched on the topic with a wider historic perspective (Northedge, 1986), or John Jackson who brilliantly focused on economic aspects (Jackson, 1969). These sources are complemented with investigations about the League of Nations and central and east Europe, whichmainly focus on partial aspects, as the refugee questions, the national minorities issue or conflicts solved by the organization. The problem of the existing research is the focus on major players as, for example, Poland, with the Estonian issues not properly addressed. On the Estonian perspective, a basic staring point is the Historical dictionary of Estonia guided by Toivo Miljan, and the work of Tina Tamman about August Torma, the Estonian permanent delegate in the League of Nations which provides a general understanding but focus on one specific person (Tamman, 2011). Perhaps, the most relevant local researcher on the topic linking Estonia and the League of Nations is Jüri Ant, but his work has been published mainly in Estonian language, decreasing its impact in the academic community (Ant, 1998). Nevertheless, it is important to remark that most of sources used for this research are the original reports published by the League of Nations on its activities.

The topic is very relevant as it analyses the impact of international organizations on peace and stability from the perspective of cooperation. It clearly represents an alternative to the current European Union and its foundations based on integration. The lack of success of the League of Nations keeping the independence of its member states contrasts with the success of the European Union guardianship over Estonia, and for extension central and east Europe, against a hypothetical Russian aggression. The research conducted by the authors outlines the contradictions of the Estonian membership in the League of Nations, its hopes and practical involvement, and lack of results in terms of protection, revealing the ineffectiveness of cooperation in cooperation with integration. There are solid numbers of studies focusing on patterns of collaboration, as cooperation and integration, perhaps more focusing on the second half of the XX century (Loth, 2015; Troitiño, 2013; Troitiño, 2008; Kerikmäe, 2009), rather than during the period of creation of the League of Nations. Nevertheless, there is only few research works focusing (Made, 2002) on the impact of the model of cooperation on the Estonian State and its struggle for survival keeping its independence in a highly unstable period. 


\section{COOPERATION VERSUS INTEGRATION: THE MODEL OF THE LEAGUE OF NATIONS AND ESTONIA}

The essence of the League of Nations was fundamentally intergovernmental, based on cooperation between states which, in good faith and in their own interest, cooperated in an international system. The main function of the League of Nations was therefore to create the structures necessary for such cooperation to develop effectively. The League of Nations model was clearly inspired by the model of international relations promoted by the United Kingdom based on cooperation without ceding national sovereignty. The model of cooperation was welcome by Estonia because the country after a long German colonization, and forced integration into the Russian Empire was very susceptible in everything related to its newly acquired national sovereignty. The birth of the Estonian nation-state was not aligned with integrationist theses where national sovereignty was blurred into the shared sovereignty of member states. Therefore, the League of Nations and its model of international relations based on cooperation, without integrationist features, was the appropriate international forum for Estonia to become a recognized international actor.

The structure of the League of Nations was dominated by the Council, which included 4 or 5 permanent members (the Soviet Union was elected as a permanent member in 1934, greatly affecting Estonia and other countries that emerged after the tsarist collapse) and 4 other rotating members. Estonia was never a member of the Council, although Finland, to which Estonia was much attached, was a non-permanent member from 1927 to 1930. In addition, Latvia was also a non-permanent member from 1936 to 1939 at a time already heavily influenced by the Soviet Union and its expansionism. The nature of the organization based on cooperation is perfectly expressed in this body since decision-making was based on unanimity, so all members had to agree to take any decision. The Assembly was a body in which all the member states of the organization were represented, each state could have up to three representatives and only one vote. This means that all states were equal in the Assembly as they all had the same rights, one vote per member country, regardless of economic capacity, geographic size, demographics or any other variable. This equalisation of the member benefited the states with less power, such as Estonia, which were equated with giants such as the United Kingdom or Germany. The most important decisions of the Assembly were taken unanimously and in some cases by a two-thirds majority. In the first meetings, which were monthly and annual, Estonia sent delegates from 
the country with a high public ${ }^{4}$ profile, and then from 1932, for the countries assemblies from 13 to 20, mainly to be present through their permanent representatives August Schmidt and Johannes Kõdar, usually accompanied by the foreign minister in turn. As for the first assemblies, in a way the most relevant for Estonia for having its hopes of maintaining its newly acquired independence protected by the international system, the scheme of the Estonian delegation was very similar. The delegation was headed by the Foreign Minister, accompanied by some diplomats from the country. When analysing the careers of the Estonian representatives during all the years of activity of the Assembly, it is striking that only one of them died naturally in Estonia, Julius Seljamaa in 1936. Johan Laidoner (military and political), Ants Piip (Foreign Minister), Ado Anderkopp (military and political), Karl Tofer (diplomat), Aleksander Hellat (Foreign Minister), Friedrich Akel (Foreign Minister), Otto Strandman ${ }^{5}$ (Foreign Minister), Jaan Tõnisson (Foreign Minister) and Johannes Kõdar (diplomat) were executed by the Soviets. The remaining Estonian representatives to the League of Nations Assembly died

${ }^{4} 1^{\text {st }}$ Assembly (1920): Johan Laidoner, Karl Robert Pusta, Jaan Kopvillem, Louis Villecourt (delegation's secretary); $2^{\text {nd }}$ Assembly (1921): Ants Piip, Kaarel Robert Pusta, Ado Anderkopp, Jaan Lattik, Julius Tennmann, Karl Tofer, August Schmidt (later changed his name to August Torma); $3^{\text {rd }}$ Assembly (1922): Ants Piip, Johan Laidoner, Karl Robert Pusta, Aleksander Hellat, Ado Anderkopp; $4^{\text {th }}$ Assembly (1923): Karl Robert Pusta, Johan Laidoner, Ado Anderkopp; $5^{\text {th }}$ Assembly (1924): Karl Robert Pusta, Johan Laidoner, Ado Anderkopp, Oskar Öpik (delegation's secretary); $6^{\text {th }}$ Assembly (1925): August Rei, Johan Laidoner, Ado Anderkopp, Oskar Öpik (delegation's secretary).

Special Assembly Question of accepting Germany as member to the League küsimuses (1926): Ants Piip, Johan Laidoner; $7^{\text {th }}$ Assembly (1926): Friedrich Akel, Johan Laidoner, Ado Anderkopp, August Schmidt, Oskar Öpik (delegation's secretary); 8 $^{\text {th }}$ Assembly (1927): Friedrich Akel, Johan Laidoner, Karl Tofer, Oskar Öpik (delegation's secretary); $9^{\text {th }}$ Assembly (1928): Hans Rebane, Johan Laidoner, Otto Strandman, Jüri Sammul (delegation's secretary); $10^{\text {th }}$ Assembly (1929): Jaan Lattik, Johan Laidoner, Jaan Tõnisson, August Schmidt, Georg Meri (delegation's secretary); $11^{\text {th }}$ Assembly (1930): Jaan Lattik, Ants Piip, August Schmidt, Elmar Kirotar; $12^{\text {th }}$ Assembly (1931): Jaan Tõnisson, Karl Robert Pusta, August Schmidt, Johannes Kõdar; Special Assembly Mandjuria question (1932): Jaan Tõnisson, August Schmidt, Johannes Kõdar; $13^{\text {th }}$ Assembly (1932): August Schmidt, Johannes Kõdar; Special Assembly Mandjuria question (1933): August Schmidt, Johannes Kõdar; 14 ${ }^{\text {th }}$ Assembly (1933): August Schmidt, Johannes Kõdar; 15th Assembly (1934): Julius Seljamaa, August Schmidt, Johannes Kõdar; Special Assembly Gran Chaco war question between Bolivia and Paraguay (1934): August Schmidt, Johannes Kõdar; Special Assembly Gran Chaco war question between Bolivia and Paraguay (1935): August Schmidt, Johannes Kõdar; $16^{\text {th }}$ Assembly (1935): Julius Seljamaa, August Schmidt, Johannes Kõdar; $17^{\text {th }}$ Assembly: (1936): Friedrich Akel, August Schmidt, Nikolai Kaasik, Johannes Kõdar; 18 ${ }^{\text {th }}$ Assembly (1937): Friedrich Akel, August Schmidt, Nikolai Kaasik, Johannes Kõdar; $19^{\text {th }}$ Assembly (1938): Karl Selter, August Schmidt, Nikolai Kaasik, Johannes Kõdar; $20^{\text {th }}$ Assembly (1939): Nikolai Kaasik, Karl Selter, Johannes Kõdar.

${ }^{5}$ Otto committed a suicide when he received notice from the NKVD to report to their offices. 
in exile, six in Sweden, and one more representative in Madrid, London and Geneva. It can therefore be said that Estonia's representation in the League of Nations became a high-risk activity that eventually led to execution or exile. Another interesting institution for Estonia in the organization chart of the League of Nations was the Court of Justice, an international tribunal to settle disputes between the members of the organization in a regulated, orderly and peaceful manner. Within the League of Nations, only 27 countries ratified the optional clause on the mandatory jurisdiction of the Court of Justice, including Estonia. The country recognized the jurisdiction of the International Court of Justice without this meaning that nonsignatory countries had to accept the Court's rulings. Therefore, in case of conflict between two signatories, the Court would decide and its sentence would be implemented immediately. In the area, Finland and Germany also ratified the clause, but not the Soviet Union, the main source of problems for Estonia. It was important for the country to be able to resolve potential conflicts with its neighbours in a peaceful manner, since, due to economic size, demographics and size, Estonia was in a position of extreme weakness vis-à-vis its giant Soviet neighbour. Estonian politicians sought a solution to the USSR's aggressiveness in this court, despite what it meant in terms of loss of sovereignty, although their efforts were in vain because Stalin never ratified or respected the work of the Court of Justice.

\section{PREVENTION OF WARS: THE CASE OF ESTONIA AND RUSSIA IN THE LEAGUE OF NATIONS}

One of the primary objectives of the League of Nations was the prevention of wars through a system of collective security. It was perfect for Estonia, despite defeating the fledgling Red Army in the Russian civil war, with the help of Finnish and German volunteers. Once the internal strife in Russia was over, the balance of power was clearly tilted toward the Soviets. Estonia's independence therefore depended on the country's international support in the face of Soviet interference. The success of the organization mediating between Sweden and Finland for the sovereignty of the Åland Islands was appreciated and thoroughly observed in Estonia and gave hope to the country. Although this effectiveness in conflict resolution was called into question with the intervention of the League of Nations in the case of Vilnius sovereignty, disputed by Lithuania and Poland, the case of Manchuria and Japan, and finally overthrown by the case of Italian aggression against Ethiopia. One of the main international supporters was the United Kingdom, 
in a way the father of the League of Nations, which supported Estonia with its navy during the conflict with Russia, but the fatigue produced by the First World War in British society prevented this military support from going further and influencing the outcome of the Russian civil war. Leon Trotsky, leader of the Russian revolution, creator of the Red Army and leader during the civil war, accused the League of Nations of being a mere instrument of capitalism on January 18, 1922. But the Estonian government was hopeful that this position would change with the rise to power of Stalin and the membership of the USSR in the organization with representation at the highest level, as a permanent member of the Council.

In 1929, Estonia became a member of the Kellogg-Briand Pact, an alliance that sought to renounce war as an instrument for resolving conflicts between its members. Its essence was later incorporated into the League of Nations following the model of peaceful resolution of conflicts between members of the organization. Estonia, as a member of the Nominating Committee ${ }^{6}$ for positions on the General Committee of the Assembly, participated in the nomination of the representative of the Soviet Union as chairman of one of the committees of the Assembly, in an attempt to normalize relations between the two countries and tie the USSR to the organization. Estonian hopes were that as the USSR was an active and important member of the League of Nations, it would not abandon the organization and respect its rules, which included respect for the national integrity of its members and the peaceful resolution of conflicts, a mistake that would cost the lives of the majority of Estonian delegates and a third of its population, killed, deported or exiled (League of Nations Assembly: Report of the Australian delegation, 1937).

August Torma, the last permanent representative to the League of Nations said of the League of Nations that it represented what Estonia sought in international relations, a system of collective security. For the same reason, according to him, the country always supported international initiatives within the framework of the League of Nations, and, for example, vigorously supported sanctions against Italy for aggression against Ethiopia (Tamman, 2011). Vahur Made, a renowned academic in this field, has assured that for Estonia the League of Nations was a place to acquire international information and make contacts. But that the main objective was the search for international guarantees of security, in the diplomatic and military field, in order to ensure its independence (Made, 2002). In both cases, the search for international protection under the umbrella of the League of Nations was unsuccessful (see further: Kerikmäe, Joamets, Pleps, Rodin, Berkmanas, 2014).

${ }^{6}$ It included eleven member countries of the organization. 


\section{THE LEAGUE OF NATIONS AND ESTONIA}

Estonia became an important repair centre for prisoners of war in the programme initiated by the League of Nations. In the case of World War I prisoners held captive in Russia (immersed in a civil war and a confrontation with Poland), an international effort was needed so that the prisoners could return to their homes. In many cases the countries for which they had fought did not exist after the war, such as the Austro-Hungarian Empire, in others the territory had become independent (as in the case of Estonia) and even some territories had changed hands. All this made the repatriation of prisoners of war held by Russia and later by the USSR a real diplomatic nightmare (absence of valid passports) and logistics. In addition, repatriation had to take place urgently as Russia was in the midst of a civil war where none of the contenders was in a position to guarantee the physical integrity of the captives or their basic needs. Faced with this desperate situation, the League of Nations acted swiftly and effectively, nominating Dr. Nansen, a Norwegian and polar explorer, as the League of Nations High Commissioner for this matter. The Norwegian worked very closely with the Estonian authorities as the main repatriation route was organised through the port of Narva, located in eastern Estonia. The city became the hub of global humanitarian associations, which flocked to help soldiers in the process of repatriation. It is estimated that some 450000 prisoners were repatriated in total, of which some 400000 were repatriated via Estonia. The city of Narva experienced one of the first internationally managed migration crises, since the repatriation of prisoners of war was joined by a significant number of people escaping from the Russian civil war using this corridor and the help of the League of Nations, so the help of Estonia in the case of a major refugee crisis treated jointly by the League of Nations was very important. Narva's strategic position, just 150 kilometres from Russia's still capital, St Petersburg, helped thousands of Russian citizens escape the civil war and go into exile (see further: Kerikmäe, 2004). Obviously, Narva was not prepared for such a flood of people and lacked the basic infrastructure to care of them, but the High Commissioner of the League of Nations, in collaboration with the Estonian government, created a real tented village around the old Narva Castle, where new arrivals were cared for, fed and provided with accommodation until their repatriation (Housden, 2014).

The League of Nations with regard to the protection of minorities took a special interest in 16 countries, mainly in Eastern Europe, including Estonia. It was a very important issue for the organization since the 
disarray created by the movement of borders and the disappearance of states after the First World War, left huge pockets of population in nation states alien to the culture of these minorities. It was an issue that took up a lot of time in the work of the Council of the League of Nations, which devoted an enormous amount of resources to resolving issues related to minority complaints and negotiations with centralist governments (Medijainen, 2002). Despite Estonia's adherence to the League of Nations chapter on the protection of minorities, some Estonian Germans were not satisfied with the nationalization of large estates and other farms. The land reform mainly affected the members of this minority and was therefore seen as discrimination on the basis of nationality, so the white Germans made various petitions to the Council of the League of Nations (Housden, 2014). In the Baltic countries there were more controversies with Lithuania and Latvia. The first country received 34 complaints, mainly from Poles, 1 Russian, 2 Ukrainians and 4 Jews. On the other hand, there were 6 complaints about Latvia, 1 from Germans and 1 from Jews in the League of Nations. And only two complaints about Estonia were referred to the organisation, the two from Baltic Germans. The two complaints related to the reform of agrarian property and the nationalization of large estates. Estonia's representative in the League of Nations argued that this reform had nothing to do with nationality or minorities, as no complaints had been received from Swedish, Russian or Jewish minorities. German, Jewish, Polish and Russian minorities had already complained to the organization even before the three countries joined the League of Nations, during the period between the creation of the organization and the incorporation of Estonia as a full member, although these complaints were never really addressed by the organization. Estonia was a relatively homogeneous country with only $10 \%$ of its population belonging to minorities. But the Council forced Estonia to accept the treaty guaranteeing the rights of minorities to become a full member of the organization. This clause was highly unusual because of its conditionality, and Estonia and Latvia refused to ratify the treaty, arguing that their independence was not related to the Treaty of Versailles or to the Paris Conference, and that national sovereignty could not be placed under the umbrella of the League of Nations if the country was not a full member. The Estonian negotiators also referred to the fact that the rights of minorities were guaranteed in the country's own constitution, so that accession to the treaty was not necessary as a sine qua non for membership of the organisation. Although, in fact, the 1920 Constitution only referred to the equality of religions and nations on Estonian territory without fully 
incorporating references to the fact that religious or national differences would not prejudice civil or political rights. Another problem was that Estonia did not automatically guarantee citizenship to those without a state, only to those born to unknown parents. The problem is related to the disappearance of the former state, the Russian empire, replaced by Estonia and the USSR, so that many people who previously had a passport from the Russian Empire, now had to choose between these two options, and some for different reasons did not apply for either of the two new citizenships and remained in legal limbo. Something similar happened with the fall of the USSR and the birth of Estonia and Russia as separate political realities, with more than 300,000 people holding UN grey passports. During the negotiations with the League of Nations, Estonia tried to evade the protection of minorities because it saw it as an attack on its national sovereignty, becoming the biggest stumbling block in the negotiations. But Lithuania's acceptance by signing the treaty for the protection of minority rights in May 1922, and Latvia's in July 1923, forced Estonia to accept it in September 1923, although at the last moment it managed to introduce a clause that prevented formal complaints about minority rights from being made from outside the country, mainly affecting Germany, the channel for complaints from Germans living in the country. During the negotiations, a League of Nations commissioner on Estonia expressed satisfaction with the treatment of Jewish and Russian minorities, relying on newspapers published by both minorities in France. Although the Council of the League of Nations had some sympathy for the Baltic Germans affected by the land reform, arguing that it had been carried out in a discriminatory manner and without a minimum principle of equality before the law in its application, it was also convinced that the expropriation of land, as an instrument of the country's social and economic consolidation, was inevitable, so no action was taken against Estonia (see further: Troitino, 2013). During the debates on the adoption of a law on the cultural autonomy of minorities in the Estonian parliament, reference to the League of Nations was frequently made both by Estonian politicians and by politicians from the Baltic German party. Minority status was granted to Jews in 1925, and cultural autonomy was granted to Baltic Germans in the same year. With regard to land reform in Estonia, when the country proclaimed its independence in February 1918, 58\% of productive land still belonged to the German minority, when 2/3 of Estonian peasants (some 500 000) had no land at all. To attract this important population group, during the war of independence the distribution of land among peasants was promised and access to land became a symbol of national freedom. In Estonia, therefore, 
land reform was more radical than in the other two Baltic countries, and the Baltic Germans never reconciled with this loss. In 1919 the vast majority of Germans lost their land and also their social status, so some emigrated to Germany, and the rest were humiliated by what they complained to the League of Nations arguing that minorities in Estonia were not protected and Germans were attacked because of their nationality (Weiss-Wendt, 2017). Among those who emigrated to Germany with great resentment was Alfred Rosenberg, born in Tallinn and Hitler's Minister for the East, head of the Nazi party while he was in prison (Cecil, 1972).

An importantfunction of the League of Nations in its quest for international stability as a guarantor of the Common Security Project was to provide its members with the financial instruments necessary for their economies to grow in a sustainable manner. The creation of a global system of international relations could not ignore the economic needs of its members, because a strong crisis affecting the socio-economic fabric of the member states would also affect their social stability, exponentially increasing the possibilities of conflicts (Troitiño, 2014). This was especially relevant after the First World War in Central and Eastern Europe, where the transformation of its newly created national markets was going through the logical problems derived from a profound change in its economic model. The League of Nations offered financial assistance to countries such as Hungary, Bulgaria, Greece and Estonia. Avenol, Monnet's substitute French banker in the organization, coordinated the League's efforts for reconstruction after the Great War, particularly focused on Central Europe, in a very important transition period after the collapse of the German and Austro-Hungarian empires. Avenol developed financial solutions for the neediest countries, including, in addition to those already mentioned, Austria and China, where French was sent on a League of Nations mission in 1929. The League of Nations finance committee assisted the free city of Danzig, Poland and Estonia by funding assistance programmes (Kuehl, Dunn, 1997). Estonia received a 7\% loan from 1927 to 1947 for the reform of its banking system and national currency. In addition, the committee made different recommendations to stabilize Estonia's economy (Kerikmäe, Gräzin, 2000), emphasizing the country's dependence on the agricultural sector, thus recommending facilitating exports of these products. It also highlighted the role of animal products, forest products and flax products. The report went on to describe the situation of the agricultural sector affected by a financial crisis because, following the nationalisation of the large estates, the land had been sold to local farmers, who faced payments thanks to very advantageous state 
credits in the long term. The financial crisis of the Estonian state and its lack of own resources prevented the continuation of the system, destabilizing the country. Those farmers who had acquired their land with short-term private credit, with higher interest rates, were dangerously exposed to a financial crisis. Faced with a hypothetical crisis in the country, the Committee proposed transforming short-term loans into long-term loans (League of Nations Economic Committee, 1931). On the other hand, the League of Nations developed a System to improve trade based on the settlement of accounts between member countries. Estonia's accounts with its main trading partners were settled in their currencies, francs with France or marks with Germany. In the early years of its independence and membership of the League of Nations, the Estonian government permanently linked its currency to the Pound Sterling, the international currency of the time, as its Finnish and Latvian neighbours had done (Report on exchange control, 1938) but the system collapsed with the strong oscillations of the system in the midst of the crisis after the economic crisis of 1929. The technical assistance function played an important role in the relationship between the League of Nations and Estonia. In 1924 the Estonian government requested the sending of financial experts from the League of Nations to examine its economic situation and propose solutions to its problems. Help from international experts to improve your internal situation with their knowledge of economics and their international experience (A short history of the League of Nations, 1929). The work of the experts sent by the League of Nations to Estonia was borne entirely by the country, which assumed their salaries and expenses, and the salaries of the assistants that the delegates deemed appropriate. In their reports they identified a major problem with the Estonian government's loans to the country's big industrialists with the aim of fostering Estonia's industrial development, but which had actually been used by the latter to invest in the stock market, which offered higher returns, but exposed them to a stock market crisis, as happened in 1929 (Troitiño, Ballesteros, 2017). Its recommendations also referred to an agrarian reform, which should be deepened by facilitating access to sources of financing for peasant landowners to improve the productivity of their activities.

\section{ESTONIAN CONTRIBUTIONS TO THE LEAGUE OF NATIONS}

The League of Nations raised great expectations worldwide as the beginning of a new era where legality would prevail over force in relations 
between states and nations. One of the most striking cases at the level of journalistic and popular attention was that of the Six Nations. The leader of the Cayuga tribe, belonging to the Iroquois confederation, Deskaheh, travelled in 1923 to the headquarters of the League of Nations in Geneva, with a passport from the Iroquois Confederation, where he presented a memorial asking for justice for his people, originally from New York. He presented the original treaty between the federation of the six nations, which included various Native American tribes, and the British colonial authorities. The Indian leader wanted this treaty to be sanctioned by the League of Nations and thus restore the rights of a people who were cornered in reserves managed by the U.S. authorities and British colonial Canada. This struggle for Native American rights was enthusiastically supported in the League of Nations by Estonia, Persia, Ireland and Panama. Delegates from these four countries wrote to the President of the Assembly on September 27, 1923 to have a new Six Nations communiqué heard at the Assembly and suggested that the Council seek the opinion of the organization's Court of Justice. Finally, the matter came to a standstill following British pressure on the four countries to suspend further action, to which they all bowed. The Six Nations issue was resolved internally by dissolving the Canadian Mounted Police from the Six Nations Parliament, stealing documentation and calling new elections. Deskaheh went into exile in the United States, where he died on the Tuscarora reservation (Veatch, 1975).

Among the functions of the League of Nations was the creation of an international system to facilitate contacts at the international level. It was a truly exciting period as the foundations were laid for a worldwide homogenization of the basic rules of coexistence, trade and social development. Previously, there had been several attempts to create common patterns that eliminated unnecessary barriers between states that affected international trade and marked differences between states, thus fostering more radical nationalism. The League of Nations founded numerous specific committees that sought to create common standards in their fields of work, initiating a globalization that still persists today. In the case of Estonia, the country joined most of these committees and applied their results in the country, some in a particular way, such as with regard to the health system, and rejected some others for economic reasons. Estonia did not ratify the 1931 Convention for the Unification of Road Signs of the League of Nations because it entailed considerable financial obligations, the country notified that it understood the importance of the Convention, but for budgetary reasons did not accede to it. In addition, it stressed that the implementation 
of the Convention would only be possible with the creation of a reserve fund of 25 million gold francs in a letter sent by the Estonian government in 1936 (League of Nations, 1936a). On the other hand, there were committees in which Estonia participated actively, such as the international uniformity of sea voyages (League of Nations,1936b).

The League of Nations had its own civil service, in many cases composed of international experts and relevant persons with extensive experience, as well as the administrative staff necessary to carry out its functions. These people were due to the League of Nations, ignoring their own nationality and seeking only the common good. Historical figures such as Jean Monnet or Salvador de Madariaga stand out (Troitiño, 2017). Estonia, due to its size and its recent incorporation into the international world, had almost no nationals among the workers of the League of Nations. The most relevant person was undoubtedly Ragnar Nurkse, an economist, specialist in the international movement of capital. He was the only Estonian working in the secretariat of the League of Nations and one of the few in the entire organization. He began working under the orders of Avenol in 1934. As an external employee, hired on merit and not appointed by any country. His nomination generated some controversy in Estonia as he had not completed his compulsory military service, creating a crisis between Defence Minister Paul Lill, who favoured blocking the appointment until Ragnar had completed his military service, and Foreign Minister Julius Seljamaa, who supported his appointment so that an Estonian citizen would occupy a relevant position within the largest international organisation of the time (Kerikmäe, 2015). In addition, the foreign minister stressed that as a merit-based recruit, he could not be replaced by another Estonian if he blocked access to the post. Two opposing visions, the military and the need to have a population prepared to defend the country through arms, and the diplomatic one, protecting the country through international cooperation, which clashed in the case of Nurske. Indeed, neither option secured the independence of Estonia, which succumbed to the powerful Soviet Union and lost its independence, but they reveal the concerns of a society obsessed with guaranteeing its autonomy by any means available. Ragnar Nurske came from a humble family, his father was a teacher, but because of his outstanding intellect he studied at the University of Tartu, the most important in the country at that time, and finally graduated in Scotland. He was fluent in many languages, common in this small country, and specialized in world economics, so his contribution to the many League of Nations reports was extremely important. The Secretary General of the League of Nations, Joseph Avenol, visited Estonia in 
1937 from 21-24 August on an official trip in which Nurske participated as a member of the delegation accompanying Avenol. Ragnar Nurske continued to work in the League of Nations even after its collapse and the suspension of its activities during World War II. Therefore, he served the organization until its end, although he relinquished his active participation in the new United Nations and devoted himself to the academic world from his chair at Princeton University in the United States (Kukk, Kukk, 2009).

\section{CONCLUSIONS}

In the long run it can be said that Estonia's membership in the League of Nations was a failure, because its main objective of securing its independence through a global security system did not work. The country was absorbed by the spiral of violence that shook the world during the late 1930s and World War II. The infamous Ribbentrop-Molotov pact meant the end of Estonia's official independence, which was already under Soviet orbit. An international agreement between two countries that skipped any rule established by the League of Nations and revealed the uselessness of the organization under pressure from powerful countries. Previously, Italy's aggression against Ethiopia had marked the effectiveness of the organisation, with Estonia fighting to impose harsh economic sanctions on Italy in order to safeguard the collective security system, even if it failed to do so by designating the League of Nations irrelevant economic sanctions and subsequently leaving the organisation Mussolini In spite of this, the numerous positive effects that the League of Nations had on Estonia described in this research cannot be ignored, both in economic terms and in terms of the country's incorporation into the world as a partner respected and accepted by the international community. Estonia's participation in the League of Nations is therefore a tale of lights and shadows that greatly excited this Baltic country and had remarkable positive effects, although for much higher reasons internationally it ended in a disaster from which Estonia is still recovering. Nevertheless, taking into consideration the main aim of Estonia to become a member of the League of Nations and the position of the country favouring a model based on cooperation rather than integration, leads this research to definitely define the national performance inside the organization as a failure. Obviously the international power and prestige of Estonia could not have altered itself the essence of the organization, but could at least, foster a dialogue forward a more stable peace system. The active participation and contributions of Estonia in the League of Nations were merely focused 
on the case of the Six Nations, the participation in regulation committees elaborating international rules, and the economic input by Ragnar Nurske, none of these are remotely linked with the main aim of the country in the membership, and none of them helped the country keep its independence from the Soviet threat.

The League of Nations played an important role in the economic development of the country, the resolution of the refugees crisis and softened the crisis generated by national minorities in Estonia, but it seems a consolation price not worthy the ineffectiveness of the organization as a peace system and the low profile maintained by the Estonian government promoting deeper integration as a way to keep their independence. It could be seen as a contradiction, sharing higher level of national sovereignty in order to keep some national autonomy, but the options of the country were much reduced due the Soviet ambition over Estonia. Hence, this research archives the main aims established at the genesis of the investigation with a negative conclusion regarding the participation of Estonia in the League of Nations as a contention to the Soviet expansion.

\section{REFERENCES}

ANT, J. (ed.). (1998). Kaks algust: Eesti Vabariik, 1920. ja 1990. aastad (Vol. 3). Eesti Riigiarhiiv, 1998.

AUFRICHT, H. (1951). Guide to League of Nations publications: a bibliographical survey of the work of the League, 1920-1947. New York: Columbia University Press, 1951, 682 p.

CECIL, R. (1972). The myth of the master race: Alfred Rosenberg and Nazi ideology. New York: Dodd, Mead \& Company, 1972, 266 p.

DUBIN, M. D. (1983). Transgovernmental processes in the League of Nations. In: International Organization. Vol. 37, No. 3, 1983, pp. 469-493.

ELLIS, C. H. (1929). The origin, structure \& working of the League of Nations. Boston: Houghton Mifflin Company (reprinted by The Lawbook Exchange, Ltd.), 1929, $528 \mathrm{p}$.

HOUSDEN, M. (2014). The League of Nations and the Organization of Peace. London: Routledge, 2014, $192 \mathrm{p}$.

HOWARD-ELLIS, C. (1928). The origin, structure and working of the League of Nations. London: Allen \& Unwin, 1928, pp. 451-477.

JACKSON, J. H. (1969). World Trade and the Law of GATT (Vol. 482). Indianapolis: Bobbs-Merrill. 1969. 
KERIKMÄE, T. (2004). The Achilles Heel of Estonia's Ownership Reform: The Case of Emigrants. In: European Journal of Law Reform. Vol. 6, No. 1/2, 2004, pp. 265-279.

KERIKMÄE, T. (2009) Estonia in the European Legal System: Protection of the Rule of Law Through Constitutional Dialogue, Tallinn University, 2009, 59 p.

KERIKMÄE, T. (2015). European History and the Future of Legal Freedoms. In: Baltic Journal of European Studies. Vol. 5, No. 2, 2015, pp. 3-4.

KERIKMÄE, T., GRÄZIN, I. (2000). Euroopa Liitja õigus.Tallinn: Õiguskirjastus, 2000, $192 \mathrm{p}$.

KERIKMÄE, T., JOAMETS, K., PLEPS, J., RODIN, A., BERKMANAS, T. (2014). The Law of the Baltic States. Cham: Springer International, 2014, $534 \mathrm{p}$.

KUEHL, W. F., DUNN, L. (1997). Keeping the covenant: American internationalists and the League of Nations, 1920-1939 (No. 10). Kent (Ohio): Kent State University Press, 1997, 408 p.

KUKK, K. (2009). The Life and Time of Ragnar Nurkse. In: KATTEL, R., KREGEL, J. A., REINERT, E. S. (eds). Ragnar Nurkse (1907-2007): Classical Development Economics and its Relevance for Today. London: Anthem Press, 2009, pp. 29-52.

LAQUA, D. (2011). Transnational intellectual cooperation, the League of Nations, and the problem of order. In: Journal of Global History. Vol. 6, No. 2, 2011, pp. 223-247.

LEAGUE OF NATIONS. (1936a). Ratification of International Conventions Concluded Under the Auspices of the League of Nations: Results of the Sixth Enquiry Addressed by the Secretary-general to the Governments Under the Assembly's Resolution of October 3rd, 1930.

LEAGUE OF NATIONS. (1936b). Uniform System of Maritime Buoyage.

LEAGUE OF NATIONS. (1938). Report on exchange control, no. 10.

LEAGUE OF NATIONS ASSEMBLY. (1937). Report of the Australian delegation. LEAGUE OF NATIONS ECONOMIC COMMITTEE. (1931). The Agricultural Crisis (Vol. 1). Geneva: League of Nations, 1931.

LOTH, W. (2015). Building Europe: A History of European Unification. Oldenbourg: De Gruyter, 2015, 485 p.

MADE, V. (2002). In search of abstract security: Estonia and the League of Nations. In: MEDIJAINEN, E., MADE, V. (eds.). Estonian Foreign Policy at the Cross-Roads. Helsinki: Kikimora Publications, 2002, pp. 25-39.

MARGARET C. PEABODY FUND (1929). A short history of the League of nations: official textbook for the third national competitive examination on the League of nations for high school students and the first national 
competitive examination on the League of nations for normal school students.

MEDIJAINEN, E., MADE, V. (eds.) (2002). Estonian Foreign Policy at the CrossRoads. Helsinki: Kikimora Publications, 2002, 170 p.

MILJAN, T. (2015). Historical dictionary of Estonia. Rowman \& Littlefield, 2015.

NORTHEDGE, F. S. (1986). The League of Nations: its life and times. Leicester: Leicester University Press, 1986.

ROSTING, H. (1923). Protection of Minorities by the League of Nations. In: American Journal of International Law, Vol.17, No. 4, 1923, pp. 641-660.

TAMMAN, T. (2011). The last ambassador: August Torma, soldier, diplomat, spy. Amsterdam: Rodopi, 2011, 270 p.

TROITIÑN, D. R. (2008). Estoniay la Unión Europea. RUE. Revista universitaria europea, Vol. 9, 2008, pp. 31-46

TROITIÑO, D. R. (2013). European Integration: Building Europe (European Political, Economic, and Security Issues). London: Nova Science Publishers, 2013, 352 p.

TROITIÑNO, D. R. (2014). The British position towards European integration: a different economic and political approach. In: Baltic Journal of European Studies, Vol. 4, No. 1, 2014, pp. 119-136.

TROITIÑNO, D. R. (2017). Jean Monnet before the first European Community: a historical perspective and critic. In: Trames: A Journal of the Humanities and Social Sciences, Vol. 21, No. 3, 2017, pp. 193-213.

TROITIÑNO, D. R., BALLESTEROS, M. D. L. P. P. (2017). El modelo de integración europea de Churchill. In: Revista de Occidente, No. 433, 2017, pp. 57-71.

VEATCH, R. (1975). Canadian foreign policy and the League of Nations, 19191939. Toronto: University of Toronto Press, 1975, 236 p.

WALTERS, F. P. (1952). A History of the League of Nations (Vol. 2, p. 716). London: Oxford University Press, 1952.

WEISS-WENDT, A. (2017). On the Margins. About the History of Jews in Estonia. Budapest: Central European University Press, 2017, 330 p. 